\title{
Corrosion inhibition potentiality of some benzimidazole derivatives for mild steel in hydrochloric acid: Electrochemical and weight loss studies
}

\author{
H. Lgaz, ${ }^{1,2}$ R. Salghi ${ }^{2} *$ and S. Jodeh ${ }^{3} *$ \\ ${ }^{1}$ Laboratory of separation processes, Faculty of Science, University Ibn Tofail, \\ PO Box 242, Kenitra, Morocco \\ ${ }^{2}$ Laboratory of Applied Chemistry and Environment, ENSA, Ibn Zohr University, \\ PO Box 1136, 80000 Agadir, Morocco \\ ${ }^{3}$ Department of Chemistry, An-Najah National University, PO Box 7, Nablus, \\ Palestine \\ *E-mail:r.salghi@uiz.ac.ma; sjodeh@hotmail.com
}

\begin{abstract}
The adsorption and inhibition effects of three benzimidazole derivatives (BDD), namely: 2-(2-pyridyl)benzimidazole (PBD), 2-bromo-1H-benzimidazole (BrBD), and 2-chlorobenzimidazole (ClBD) on mild steel corrosion in $1 \mathrm{M} \mathrm{HCl}$ have been studied by electrochemical and weight loss methods. Results showed that inhibition efficiency increases with concentration and maximum value was obtained at $5 \cdot 10^{-3} \mathrm{M}$ concentration. From the results, it is concluded that the BDD inhibited mild steel corrosion in $1 \mathrm{M} \mathrm{HCl}$ by adsorbing on the metal surface. Polarization results showed that the BDD act as mixed type inhibitors. The adsorption of BDD onto the mild steel surface was described by the Langmuir adsorption isotherm.
\end{abstract}

Keywords: corrosion inhibition, mild steel, EIS, weight loss, benzimidazole derivatives.

Received: July 28, 2016. Published: October 12, 2016.

doi: $\underline{10.17675 / 2305-6894-2016-5-4-5}$

\section{Introduction}

Acid solutions are commonly used for pickling, industrial acid cleaning, acid descaling, and oil-well acidifying processes [1-3]. Because of the aggressiveness of acid solutions, mild steel corrodes severely during these processes, particularly with the use of hydrochloric acid, which results in terrible waste of both resources and money. A corrosion inhibitor is often added to mitigate the corrosion of metal by acid attack [4-7]. Most wellknown corrosion inhibitors are organic compounds containing polar groups including nitrogen, sulfur, and/or oxygen atoms and heterocyclic compounds with polar functional groups and conjugated double bonds [8-10]. The inhibiting action of these compounds is due to the adsorption of these compounds to the metal/solution interface. The adsorption process depends upon the nature and surface charge of the metal, the type of aggressive media, the structure of the inhibitor and the nature of its interaction with the metal surface [11-13]. The choice of these compounds is based on molecular structure considerations, 
i.e., the number of active centers and type of substituents present in these compounds [14$16]$.

The objective of this work is to investigate the corrosion inhibition properties of three benzimidazole derivatives, namely, 2-(2-pyridyl)benzimidazole (PBD), 2-bromo-1 Hbenzimidazole (BrBD), and 2-chlorobenzimidazole (ClBD) on mild steel in $1 \mathrm{M} \mathrm{HCl}$ using electrochemical techniques and weight loss studies.

\section{Experiment}

\section{Electrodes, chemicals and test solution}

Corrosion tests have been performed, using the gravimetric and electrochemical measurements, on electrodes cut from sheets of mild steel with the chemical composition: $0.370 \%$ C, $0.230 \% \mathrm{Si}, 0.680 \% \mathrm{Mn}, 0.016 \% \mathrm{~S}, 0.077 \% \mathrm{Cr}, 0.011 \% \mathrm{Ti}, 0.059 \% \mathrm{Ni}, 0.009 \%$ $\mathrm{Co}, 0.160 \% \mathrm{Cu}$, and the remainder iron.

The aggressive medium of molar hydrochloric acid used for all studies were prepared by dilution of analytical grade $37 \% \mathrm{HCl}$ with double distilled water. The concentrations of BDD used in this investigates were varied from $5 \cdot 10^{-4}$ to $5 \cdot 10^{-3} \mathrm{M}$. The inhibitors molecule used in this paper was purchased from Sigma-Aldrich and have the structure presented in Figure 1. As can be seen, they have different active groups, which can act as adsorption centers.

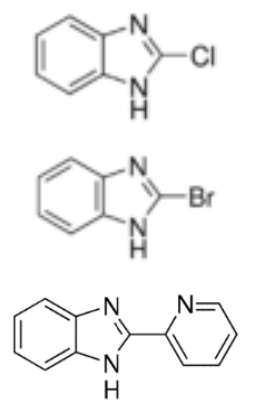

2-Chlorobenzimidazole (ClBD)

2-Bromo-1H-benzimidazole (BrBD)

2-(2-Pyridyl)benzimidazole (PBD)

Figure 1. Chemical structure of inhibitors.

\section{Gravimetric measurements}

Gravimetric measurements were realized in a double walled glass cell equipped with a thermostat-cooling condenser. The carbon steel specimens used have a rectangular form with dimension of $2.5 \times 2.0 \times 0.2 \mathrm{~cm}$ were abraded with a different grade of emery paper (320-800-1200) and then washed thoroughly with distilled water and acetone. After weighing accurately, the specimens were immersed in beakers which contained $100 \mathrm{ml}$ acid solutions without and with various concentrations of BDD at temperature equal to $303 \mathrm{~K}$ maintained by a water thermostat for $6 \mathrm{~h}$ as immersion time. The gravimetric tests were performed in triplicate at the same conditions. 
The corrosion rates $\left(C_{R}\right)$ and the inhibition efficiency $\left(\eta_{w l} \%\right)$ of carbon steel have been evaluated from mass loss measurement using the following equations:

$$
\begin{gathered}
C_{R}=\frac{w}{S t}, \\
\eta_{w t} \%=\frac{C_{R}^{0}-C_{R}}{C_{R}^{0}} \times 100,
\end{gathered}
$$

where $w$ is the average weight loss before and after exposure, respectively, $S$ is the surface area of sample, $t$ is the exposure time, $C_{R}^{0}$ and $C_{R}$ is the corrosion rates of steel without and with the BDD inhibitor, respectively.

\section{Electrochemical tests}

The potentiodynamic polarization curves were conducted using an electrochemical measurement system PGZ 100 Potentiostat/Galvanostat controlled by a PC supported by the Voltamaster 4.0 Software. The electrochemical measurements were performed in a conventional three electrode glass cell with carbon steel as a working electrode, platinum as counter electrode $(\mathrm{Pt})$ and a saturated calomel electrode used as a reference electrode. The working electrode surface was prepared as described above gravimetric section. Prior to each electrochemical test an immersion time of $30 \mathrm{~min}$ was given to allow system stabilization at corrosion potential. The polarization curves were obtained by changing the electrode potential automatically from -800 to $-200 \mathrm{mV} / \mathrm{SCE}$ at a scan rate of $1 \mathrm{mV} \mathrm{s}^{-1}$. The temperature is thermostatically controlled at desired temperature $\pm 1 \mathrm{~K}$. The percentage protection efficiency $\left(\eta_{P D P} \%\right)$ is defined as:

$$
\eta_{P D P}(\%)=\frac{I_{\text {corr }}^{0}-I_{\text {corr }}}{I_{\text {corr }}^{0}} \times 100,
$$

where $I_{\text {corr }}^{0}$ are corrosion current in the absence of inhibitor, $I_{\text {corr }}$ are corrosion current in the presence of inhibitor.

Electrochemical impedance spectroscopy (EIS) measurements were carried out with same equipment used for potentiodynamic polarization study (Voltalab PGZ 100) at applied sinusoidal potential waves of $5 \mathrm{mV}$ amplitudes with frequencies ranging from $100 \mathrm{KHz}$ to $10 \mathrm{mHz}$ at corrosion potential. The impedance diagrams are given in the Nyquist representation. The charge transfer resistance $\left(R_{\mathrm{ct}}\right)$ was determined from Nyquist plots and double layer capacitance $\left(C_{\mathrm{dl}}\right)$ was calculated from CPE parameters of the equivalent circuit deduced using Zview software. In this case the percentage protection efficiency $\left(\eta_{E I S} \%\right)$ is can be calculated by the value of the charge transfer resistance $\left(R_{\mathrm{ct}}\right)$

$$
\eta_{E I S}(\%)=\frac{R_{\mathrm{ct}}-R_{\mathrm{ct}}^{0}}{R_{\mathrm{ct}}} \times 100
$$


where $R_{\mathrm{ct}}$ and $R_{\mathrm{ct}}^{0}$ are the polarization resistance of uninhibited and inhibited solutions, respectively.

\section{Results and discussion}

\section{Weight loss study}

Weight loss measurements were carried out in $1.0 \mathrm{M} \mathrm{HCl}$ in the absence and presence of different concentrations of BDD at $303 \mathrm{~K}$ after $6 \mathrm{~h}$ immersion period. Table 1 presents the corrosion rate, inhibition efficiency $\left(\eta_{w l} \%\right)$ for benzimidazole derivatives at different concentrations. The results show that three compounds inhibit the corrosion of mild steel in 1.0 $\mathrm{M} \mathrm{HCl}$ solutions given that the corrosion rate was reduced in the presence of the BDD compared to the blank solution. The corrosion rate was found to depend on the concentration of the BDD. Inspection of the table revealed a decrease in corrosion rate as the concentration of the BDD increased. It could be also observed from the Table 1 that inhibition efficiency increased with increase in the concentration of the BDD. It is noted that the maximum inhibition efficiency obtained for PBD, BrBD and ClBD are 97\%, 95\% and $93 \%$ respectively at $303 \mathrm{~K}$ with the highest concentration $\left(5 \cdot 10^{-3} \mathrm{M}\right)$ of the BDD studied. This indicates that BDD are better corrosion inhibitors. The inhibition behavior of these BDD for mild steel corrosion in the acidic medium can be attributed to the adsorption of the components on the mild steel surface, which retards the dissolution of the metal by blocking its active corrosion sites $[17,18]$. Consequently, the corrosion rate is reduced and the inhibition efficiency is increased as the BDD concentration is increased.

Table 1. Inhibition efficiency of various concentrations of BDD for corrosion of MS in $1 \mathrm{M} \mathrm{HCl}$ obtained by weight loss measurements at $303 \mathrm{~K}$.

\begin{tabular}{ccccc}
\hline Inhibitors & Concentration $(\mathbf{M})$ & $\boldsymbol{C}_{\mathbf{R}}\left(\mathbf{m g ~ c m}^{-\mathbf{2}} \mathbf{h}^{\mathbf{- 1}}\right)$ & $\boldsymbol{\eta}_{\boldsymbol{w l}}(\mathbf{\%})$ & $\boldsymbol{\Theta}$ \\
\hline Blank & 1.0 & 1.135 & - & - \\
\hline \multirow{2}{*}{ PBD } & $5 \cdot 10^{-3}$ & 0.0320 & 97.18 & 0.9718 \\
& $1 \cdot 10^{-3}$ & 0.0671 & 94.08 & 0.9408 \\
& $5 \cdot 10^{-4}$ & 0.0984 & 91.33 & 0.9133 \\
\hline \multirow{2}{*}{ BrBD } & $5 \cdot 10^{-3}$ & 0.0519 & 95.43 & 0.9543 \\
& $1 \cdot 10^{-3}$ & 0.0879 & 92.25 & 0.9225 \\
& $5 \cdot 10^{-4}$ & 0.1299 & 88.55 & 0.8855 \\
\hline \multirow{2}{*}{ ClBD } & $5 \cdot 10^{-3}$ & 0.0705 & 93.78 & 0.9378 \\
& $1 \cdot 10^{-3}$ & 0.1122 & 90.11 & 0.9011 \\
& $5 \cdot 10^{-4}$ & 0.1457 & 87.16 & 0.8716 \\
\hline
\end{tabular}




\section{Polarization results}

The potentiodynamic polarization curves for mild steel in $1 \mathrm{M} \mathrm{HCl}$ solution at $303 \mathrm{~K}$ in the absence and presence of various concentrations of the studied BDD are presented in Figure 2. The curves are shifted to lower current regions in the presence of inhibitors showing that the studied benzimidazole derivatives inhibit the corrosion reaction. It is observed that the polarization curve for PBD (at $5 \cdot 10^{-3} \mathrm{M}$ ) appeared at lower current region than those of $\mathrm{BrBD}$ and $\mathrm{ClBD}$.
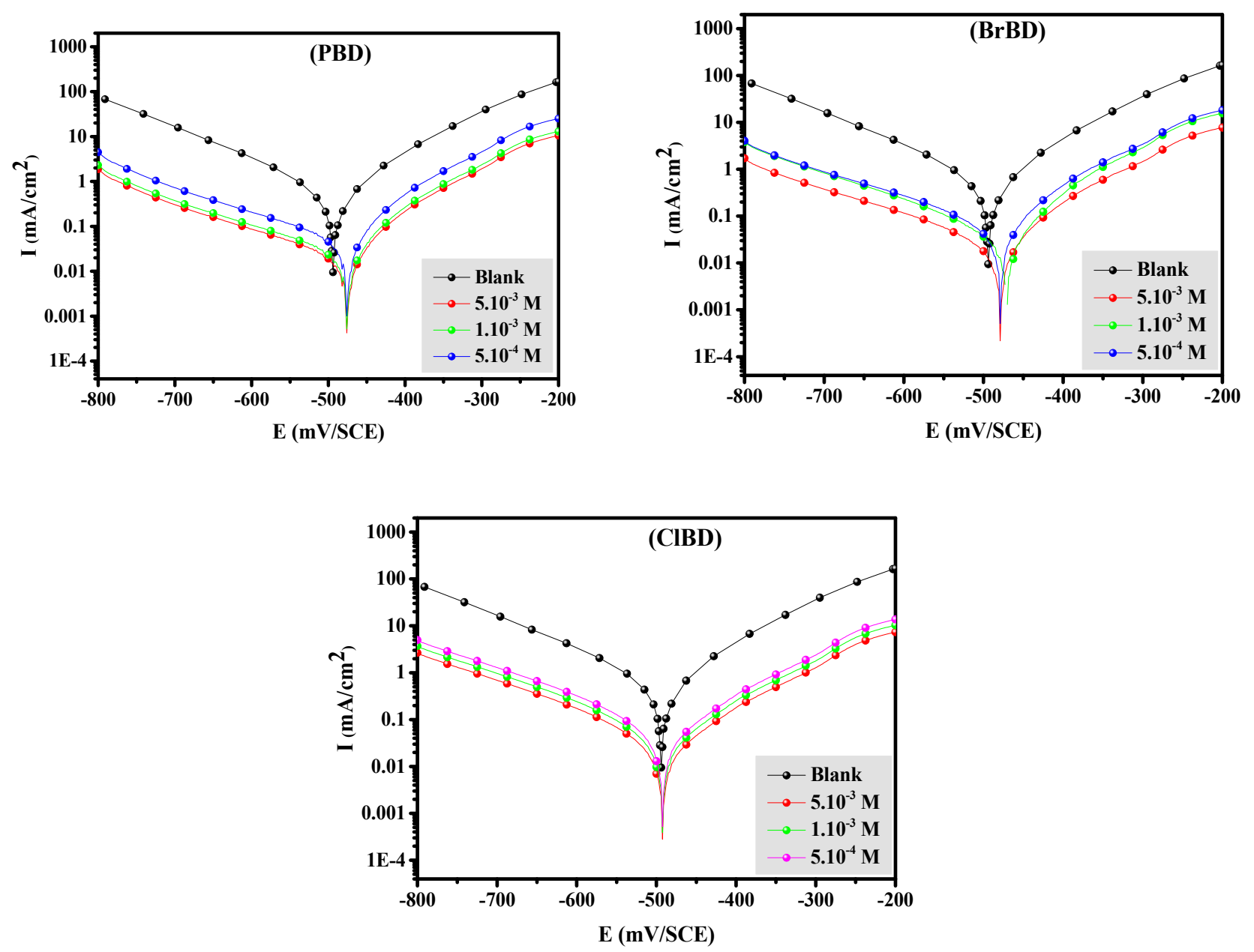

Figure 2. Polarisation curves of MS in $1 \mathrm{M} \mathrm{HCl}$ for various concentrations of BDD at $303 \mathrm{~K}$.

The linear Tafel segments of anodic and cathodic curves were extrapolated to the corrosion potential $\left(E_{\text {corr }}\right)$ to obtain corrosion current density $\left(i_{\text {corr }}\right)$. The values of electrochemical kinetic parameters obtained from the Tafel fitting of the polarization curves are presented in Table 2 . The shift in $E_{\text {corr }}$ values of the inhibited systems compared to the blank solutions is less than $80 \mathrm{mV}$, suggesting that the studied benzimidazole derivatives are mixed type inhibitors [19-21]. That is, they inhibit both the anodic 
dissolution of mild steel and the cathodic $\mathrm{H}^{+}$ion reduction. The cathodic Tafel lines show similar shape either in presence or absence of BDD. It indicates that the mechanism of the cathodic reaction does not change in presence of the inhibitor and the inhibition action is achieved by simple blocking of the iron surface [22,23]. The inhibition efficiency $\left(\eta_{P D P} \%\right)$ increases with increase in concentration for the three BDD with PBD showing the highest values of $\eta_{P D P} \%$. This implies that the studied BDD inhibit mild steel corrosion in $1 \mathrm{M} \mathrm{HCl}$ and the strength of their inhibition potential increases with the presence of $\mathrm{Cl}, \mathrm{Br}$ and pyridyl groups in its structure in the following trend: pyridyl $>\mathrm{Br}>\mathrm{Cl}$.

Table 2. Corrosion parameters for corrosion of MS with selected concentrations of BDD in $1 \mathrm{M} \mathrm{HCl}$ by potentiodynamic polarization method at $303 \mathrm{~K}$.

\begin{tabular}{|c|c|c|c|c|c|}
\hline Inhibitor & $\begin{array}{c}\text { Concentration } \\
\text { (M) }\end{array}$ & $\begin{array}{c}-E_{\text {corr }} \\
(\mathrm{mV} / \mathrm{SCE})\end{array}$ & $\begin{array}{c}I_{\text {corr }} \\
\left(\mu \mathrm{A} \mathrm{cm}^{-2}\right)\end{array}$ & $\eta_{P D P}(\%)$ & $\boldsymbol{\theta}$ \\
\hline Blank & - & 496 & 564.0 & - & - \\
\hline \multirow{3}{*}{ PBD } & $5 \cdot 10^{-3}$ & 477 & 14.21 & 97.48 & 0.9748 \\
\hline & $1 \cdot 10^{-3}$ & 475 & 26.32 & 95.33 & 0.9533 \\
\hline & $5 \cdot 10^{-4}$ & 476 & 47.98 & 91.49 & 0.9149 \\
\hline \multirow{3}{*}{ BrBD } & $5 \cdot 10^{-3}$ & 481 & 28.24 & 94.99 & 0.9499 \\
\hline & $1 \cdot 10^{-3}$ & 473 & 52.73 & 90.65 & 0.9065 \\
\hline & $5 \cdot 10^{-4}$ & 482 & 73.33 & 86.99 & 0.8699 \\
\hline \multirow{3}{*}{ ClBD } & $5 \cdot 10^{-3}$ & 491 & 39.84 & 92.93 & 0.9293 \\
\hline & $1 \cdot 10^{-3}$ & 493 & 62.42 & 88.93 & 0.8893 \\
\hline & $5 \cdot 10^{-4}$ & 490 & 78.54 & 86.07 & 0.8607 \\
\hline
\end{tabular}

\section{EIS study}

Electrochemical impedance measurements were undertaken to provide information on the kinetics of the electrochemical processes at the mild steel/acid interface and how this is modified by the presence of inhibitors. Nyquist plots for mild steel corrosion in $1 \mathrm{M} \mathrm{HCl}$ solution in the absence and presence of different concentrations $\left(5 \cdot 10^{-4}-5 \cdot 10^{-3} \mathrm{M}\right)$ of the inhibitors $\mathrm{PBD}, \mathrm{BrBD}$ and $\mathrm{ClBD}$ are given in Figure 3, respectively. The Nyquist plots show single semicircles for all systems over the frequency range studied, corresponding to one time constant [24-26]. 

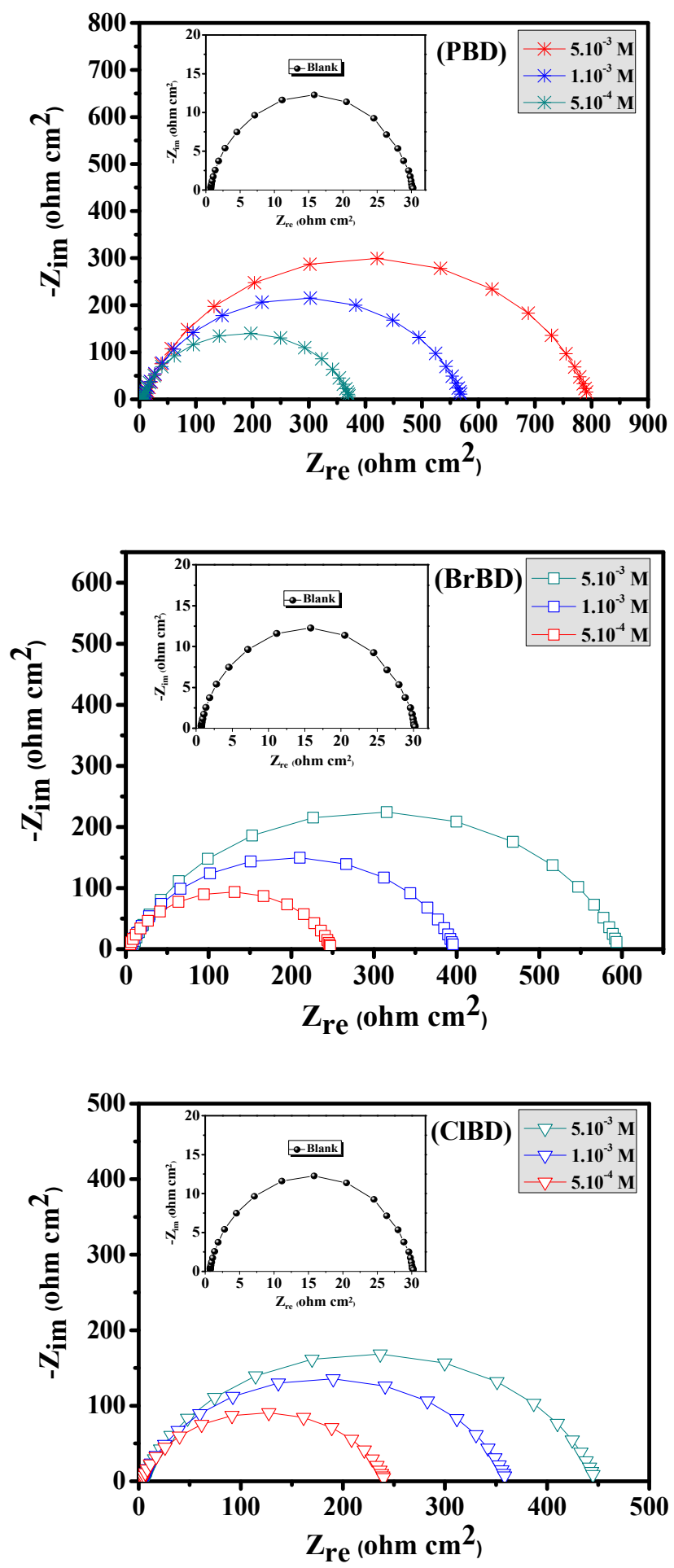

Figure 3. Nyquist curves for mild steel in $1 \mathrm{M} \mathrm{HCl}$ for selected concentrations of BDD at $303 \mathrm{~K}$. 
The impedance spectra were analyzed by fitting to the equivalent circuit model shown in Figure 4, which has been used previously to adequately model the mild steel/acid interface [27,28], where $R_{\mathrm{S}}$ is the solution resistance, $R_{\mathrm{ct}}$ denotes the charge-transfer resistance and $\mathrm{CPE}$ is constant phase element. The introduction of CPE into the circuit was necessitated to explain the depression of the capacitance semicircle, which corresponds to surface heterogeneity resulting from surface roughness, impurities, and adsorption of inhibitors $[29,30]$. The impedance of this element is frequency-dependent and can be calculated using the Eq. (5):

$$
Z_{\mathrm{CPE}}=\frac{1}{Q(j \omega)^{n}},
$$

where $Q$ is the CPE constant (in $\Omega^{-1} \mathrm{~S}^{n} \mathrm{~cm}^{-2}$ ), $\omega$ is the angular frequency (in $\mathrm{rad} \mathrm{s}^{-1}$ ), $j^{2}=$ -1 is the imaginary number and $n$ is a CPE exponent which can be used as a gauge for the heterogeneity or roughness of the surface [31,32]. In addition, the double layer capacitances, $C_{\mathrm{d}}$, for a circuit including a CPE were calculated by using the following Eq. (6):

$$
C_{\mathrm{dl}}=\left(Q \cdot R_{\mathrm{ct}}^{1-n}\right)^{1 / n} .
$$

The fitted parameters along with percentage inhibition efficiencies, $\left(\eta_{E I S} \%\right)$ are tabulated in Table 3. For all the inhibitors, diameter of the capacitive loop is seen to increase gradually with concentration, which is manifested in progressively increasing $R_{\mathrm{ct}}$ values with concomitant decrease in values of the double layer capacitance, $C_{\mathrm{dl}}$. This suggests that the extent of adsorption increases with concentration of the inhibitors and thereby provides better barrier towards charge transfer reactions at the metal-solution interface $[23,31,32]$. Percentage inhibition efficiency in terms of $R_{\mathrm{ct}}$ values $\left(\eta_{E I S} \%\right)$ are found to follow the order PBD $>$ BrBD $>$ ClBD; i.e., the same trend as observed from polarization experiment. It also supports the fact that presence of pyridine group provides better adsorption potentiality for PBD, than those for $\mathrm{Br}$ and $\mathrm{Cl}$ atoms in $\mathrm{BrBD}$ and $\mathrm{ClBD}$, respectively.

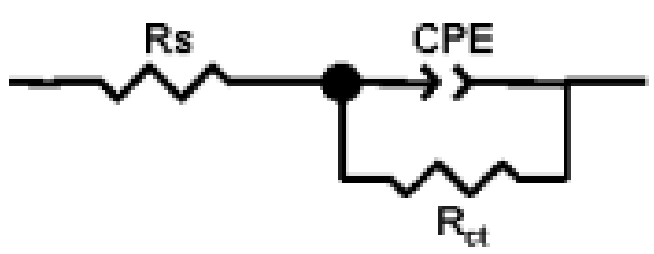

Figure 4. Equivalent electrical circuit corresponding to the corrosion process on the carbon steel in hydrochloric acid. 
Table 3. AC-impedance parameters for corrosion of mild steel for selected concentrations of BDD in $1 \mathrm{M}$ $\mathrm{HCl}$ at $303 \mathrm{~K}$.

\begin{tabular}{cccccccc}
\hline Inhibitor & $\begin{array}{c}\text { Concentration } \\
(\mathbf{M})\end{array}$ & $\begin{array}{c}\boldsymbol{R}_{\mathbf{c t}} \\
\left(\boldsymbol{\Omega} \mathbf{~ c m}^{2}\right)\end{array}$ & $\boldsymbol{n}$ & $\begin{array}{c}\boldsymbol{Q} \times \mathbf{1 0}^{-\mathbf{4}} \\
\left(\mathbf{s}^{\mathbf{n}} \mathbf{\Omega}^{-\mathbf{1}} \mathbf{c m}^{-\mathbf{2}}\right)\end{array}$ & $\begin{array}{c}\boldsymbol{C}_{\mathbf{d l}} \\
\left(\boldsymbol{\mu} \mathbf{F} \mathbf{c m}^{-\mathbf{2}}\right)\end{array}$ & $\begin{array}{c}\boldsymbol{\eta}_{\boldsymbol{E I S}} \\
(\mathbf{\%})\end{array}$ & $\boldsymbol{\Theta}$ \\
\hline Blank & 1.0 & 29.35 & 0.910 & 1.7610 & 91.6 & - & - \\
\hline \multirow{2}{*}{ PBD } & $5 \cdot 10^{-3}$ & 786.6 & 0.901 & 0.1776 & 11.10 & 96.26 & 0.9626 \\
& $1 \cdot 10^{-3}$ & 565.4 & 0.879 & 0.2812 & 15.90 & 94.80 & 0.9480 \\
& $5 \cdot 10^{-4}$ & 368.7 & 0.853 & 0.3943 & 19.01 & 92.03 & 0.9203 \\
\hline \multirow{2}{*}{ BrBD } & $5 \cdot 10^{-3}$ & 590 & 0.845 & 0.2868 & 13.57 & 95.02 & 0.9502 \\
& $1 \cdot 10^{-3}$ & 393.3 & 0.883 & 0.4032 & 23.28 & 92.53 & 0.9253 \\
& $5 \cdot 10^{-4}$ & 245.8 & 0.894 & 0.5371 & 32.15 & 88.05 & 0.8805 \\
\hline \multirow{2}{*}{ ClBD } & $5 \cdot 10^{-3}$ & 442.5 & 0.904 & 0.3342 & 21.36 & 93.36 & 0.9336 \\
& $1 \cdot 10^{-3}$ & 356.4 & 0.874 & 0.4521 & 24.93 & 91.76 & 0.9176 \\
& $5 \cdot 10^{-4}$ & 238.4 & 0.854 & 0.6778 & 33.48 & 87.68 & 0.8768 \\
\hline
\end{tabular}

\section{Adsorption isotherm}

Results so far obtained indicate that the primary mode of interaction of PBD, BrBD and CIBD on steel surface is by adsorption. The adsorption of organic inhibitor molecules from the aqueous solution can be considered as a quasi-substitution process between the organic compounds in the aqueous phase $\left[\mathrm{Org}_{(\mathrm{sol})}\right]$ and water molecules associated with the metallic surface $\left[\mathrm{H}_{2} \mathrm{O}_{(\text {ads }}\right]$ as represented by the following equilibrium $[33,34]$ :

$$
\operatorname{Org}_{(\text {sol) }}+x \mathrm{H}_{2} \mathrm{O}_{(\mathrm{ads})} \leftrightarrow \operatorname{Org}_{(\mathrm{ads})}+x \mathrm{H}_{2} \mathrm{O}_{\text {(sol) }} \text {, }
$$

where $x$ is the number of water molecules replaced by one organic molecule. In this situation, the adsorption of benzimidazole derivatives was accompanied by desorption of water molecules from the mild steel surface. The degree of surface coverage $(\Theta)$ was evaluated from the weight loss measurements. In $1 \mathrm{M} \mathrm{HCl}$, BDD adsorption follows the Langmuir isotherm (Figure 5) as per Eq.7 [35]:

$$
\frac{C}{\Theta}=\frac{1}{K_{\text {ads }}}+C,
$$

where $C$ is the concentration of the inhibitor, $K_{\text {ads }}$ is the equilibrium constant of adsorption and $\Theta$ is the surface coverage. The Langmuir approach is based on a molecular kinetic model of the adsorption-desorption process. On the other hand, the adsorption equilibrium constant $\left(K_{\text {ads }}\right)$ is related to the standard free energy of adsorption $\left(\Delta G_{\text {ads }}^{0}\right)$ of the inhibitor molecules by the following Eq. 8: 


$$
K_{\text {ads }}=\frac{1}{55.5} \exp \left(\frac{-\Delta G_{\mathrm{ads}}^{0}}{R T}\right)
$$

where $R$ is the universal gas constant, $T$ the absolute temperature in $\mathrm{K}$, and 55.5 represents the molar concentration of water in the solution. Calculated values of $K_{\text {ads }}$ and $\Delta G_{\text {ads }}^{0}$ are listed in Table 4 . The negative values of $\Delta G_{\mathrm{ads}}^{0}$ reveal the spontaneity of adsorption process $[36,37]$. In general, values of $\Delta G_{\text {ads }}^{0}$ up to $-20 \mathrm{~kJ} / \mathrm{mol}$ are compatible with physisorption and those which are more negative than $-40 \mathrm{~kJ} / \mathrm{mol}$ involve chemisorption $[38,39]$. The calculated $\Delta G_{\text {ads }}^{0}$ values for PBD, BrBD and ClBD were found to be $-35.67,-35.31$ and -35.09 , respectively, at temperatures of $303 \mathrm{~K}$, these values were between the threshold values for physical adsorption and chemical adsorption, indicating that the adsorption process of these inhibitors at mild steel surface involves both the physical as well as chemical adsorption $[40,41]$.

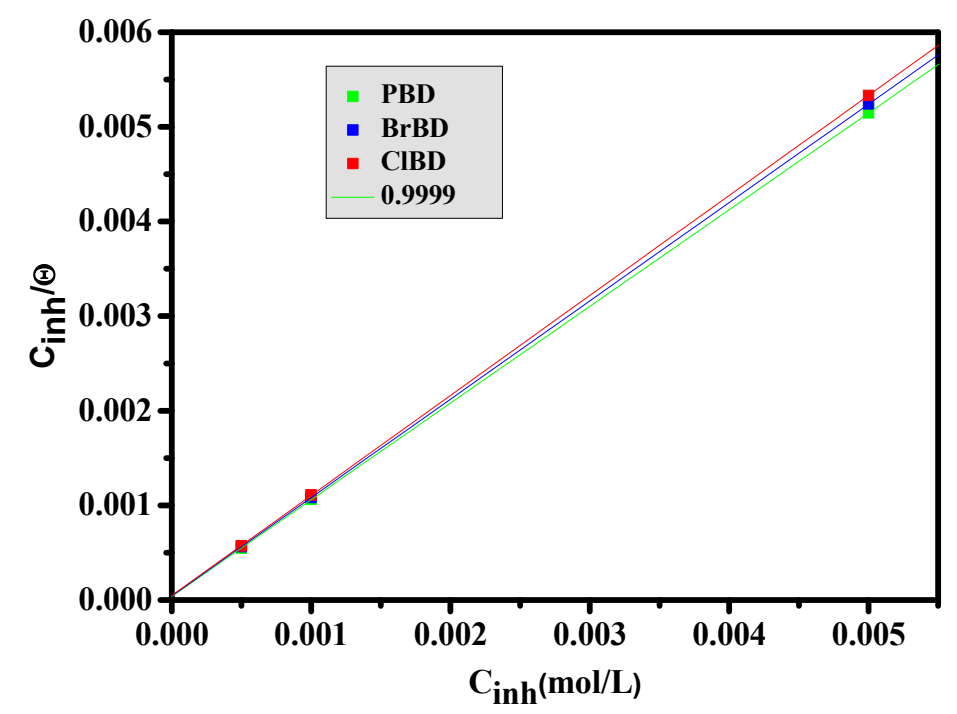

Figure 5. Langmuir adsorption of inhibitor on the MS surface in $1.0 \mathrm{M} \mathrm{HCl}$ solution at $303 \mathrm{~K}$.

Table 4. Adsorption parameters of inhibitor for MS corrosion in $1 \mathrm{M} \mathrm{HCl}$ at $303 \mathrm{~K}$

\begin{tabular}{cccc}
\hline Inhibitor & Slope & $\boldsymbol{K}_{\text {ads }}\left(\mathbf{M}^{-\mathbf{1}}\right)$ & $\Delta \boldsymbol{G}_{\text {ads }}^{\mathbf{0}}(\mathbf{k J} / \mathbf{m o l})$ \\
\hline PBD & 1.02 & 25596 & -35.67 \\
BrBD & 1.03 & 22164 & -35.31 \\
ClBD & 1.05 & 20384 & -35.09 \\
\hline
\end{tabular}




\section{Conclusion}

The corrosion inhibition of benzimidazole compounds PBD, BrBD and ClBD for mild steel in $1 \mathrm{M} \mathrm{HCl}$ was evaluated using chemical and electrochemical measurements. The obtained results showed that these compounds have good inhibition efficiency, which increases with the inhibitor concentration and follows the order: $\mathrm{PBD}>\mathrm{BrBD}>\mathrm{ClBD}$. The value of adsorption equilibrium constant $(K)$ suggested that these derivatives are strongly adsorbed on the mild steel surface according to Langmuir adsorption isotherm. Potentiodynamic polarization study shows that studied inhibitors are a mixed type inhibitors.

\section{References}

1. I. Obot and N. Obi-Egbedi, Corros. Sci., 2010, 52, 282.

2. M.A. Quraishi, Ind. Eng. Chem. Res., 2014, 53, 2851.

3. C.B. Verma, M. Quraishi and A. Singh, J. Taiwan Inst. Chem. Eng., 2015, 49, 229.

4. S. Muthumanickam, B. Jeyaprabha, R. Karthik, A. Elangovan and P. Prakash, Int. J. Corros. Scale Inhib., 2015, 4, no. 4, 365. doi: 10.17675/2305-6894-2015-4-4-6

5. L. Afia, R. Salghi, L. Bammou, E. Bazzi, B. Hammouti, L. Bazzi and A. Bouyanzer, J. Saudi Chem. Soc., 2014, 18, 19. doi: 10.1016/j.jscs.2011.05.008

6. T. Ghazouani, D.B. Hmamou, E. Meddeb, R. Salghi, O. Benali, H. Bouya, B. Hammouti and S. Fattouch, Res. Chem. Intermed., 2014, 41, 7463.

7. A. Popova, M. Christov, A. Vasilev and Chr. Girginov, Int. J. Corros. Scale Inhib., 2015, 4, 382. doi: $\underline{10.17675 / 2305-6894-2015-4-4-7}$

8. D. Daoud, T. Douadi, S. Issaadi and S. Chafaa, Corros. Sci., 2014, 79, 50. doi: 10.1016/j.corsci.2013.10.025

9. A.O. Yüce and G. Kardaş, Corros. Sci., 2012, 58, 86. doi: 10.1016/j.corsci.2012.01.013

10. A.G. Berezhnaya, V.I. Mishurov, V.V. Ekilik and Sh.Z. Lomidze, Int. J. Corros. Scale Inhib., 2013, 2, no. 4, 311. doi: 10.17675/2305-6894-2013-2-4-311-317

11. M. Lebrini, F. Robert, H. Vezin and C. Roos, Corros. Sci., 2010, 52, 3367. doi: 10.1016/j.corsci.2010.06.009

12. S. Kharchouf, L. Majidi, M. Bouklah, B. Hammouti, A. Bouyanzer and A. Aouniti, Arab. J. Chem., 2014, 7, 680. doi: 10.1016/j.arabjc.2010.12.002

13. G. Moretti, F. Guidi and F. Fabris, Corros. Sci., 2013, 76, 206. doi: 10.1016/j.corsci.2013.06.044

14. R. Solmaz, Corros. Sci., 2014, 81, 75. doi: 10.1016/j.corsci.2013.12.006

15. R. Yıldız, A. Döner, T. Doğan and İ. Dehri, Corros. Sci. 2014, 82, 125. doi: $\underline{10.1016 /}$ j.corsci.2014.01.008

16. A. Espinoza-Vázquez， G.E. Negrón-Silva， R. onzález-Olvera， D. Angeles-Beltrán, H. Herrera-Hernández, M. Romero-Romo and M. Palomar-Pardavé, Mater. Chem. Phys., 2014, 145, 407. doi: 10.1016/j.matchemphys.2014.02.029

17. M. Bouklah, M. Kaddouri, Y. Toubi, B. Hammouti and E.E. Ebenso, Int. J. Electrochem. Sci., 2013, 8, 7437. 
18. M. Parveen, M. Mobin and S.Zehra, RSC $A d v .$, 2016, 6, 61235. doi: 10.1039/ C6RA10010D.

19. D.B. Hmamou, R. Salghi, A. Zarrouk, B. Hammouti, O. Benali, H. Zarrok and S.S. AlDeyab, Res. Chem. Intermed., 2013, 39, 3475.

20. L. Afia, R. Salghi, O. Benali, S. Jodeh, S.S. Al-Deyab and B. Hammouti, Trans. Indian Inst. Met., 2015, 68, 521.

21. D.B. Hmamou, R. Salghi, A. Zarrouk, H. Zarrok, R. Touzani, B. Hammouti and A. El Assyry, J. Environ. Chem. Eng., 2015, 3, 2031. doi: 10.1016/j.jece.2015.03.018

22. I.A. Zaafarany and H.A. Ghulman, Int. J. Corros. Scale Inhib., 2013, 2, no. 2, 82. doi: 10.17675/2305-6894-2013-2-2-082-091

23. M. Yadav, R.R. Sinha, T.K. Sarkar, I. Bahadur and E.E. Ebenso, J. Mol. Liq., 2015, 212, 686. doi: 10.1016/j.molliq.2015.09.047

24. K.K. Anupama, K. Ramya and A. Joseph, J. Mol. Liq., 2016, 216, 146. doi: 10.1016/ j.molliq.2016.01.019

25. Y. Sasikumar, A.S. Adekunle, L.O. Olasunkanmi, I. Bahadur, R. Baskar, M.M. Kabanda, I.B. Obot and E.E. Ebenso, J. Mol. Liq., 2015, 211, 105. doi: 10.1016/j.molliq. 2015.06.052

26. M. Yadav, S. Kumar, R.R. Sinha, I. Bahadur and E.E. Ebenso, J. Mol. Liq., 2015, 211, 135. doi: $10.1016 /$ j.molliq.2015.06.063

27. L. Adardour, H. Lgaz, R. Salghi, M. Larouj, S. Jodeh, M. Zougagh, I. Warad and H. Oudda, Pharm. Lett., 2016, 8, 126.

28. M. Saadouni, M. Larouj, R. Salghi, H. Lgaz, S. Jodeh, M. Zougagh and A. Souizi, Pharm. Lett., 2016, 8, 96.

29. M. Yadav, R.R. Sinha, S. Kumar, I. Bahadur and E.E. Ebenso, J. Mol. Liq., 2015, 208, 322. doi: $10.1016 / \mathrm{j}$. molliq.2015.05.005

30. N.K. Gupta, C. Verma, M.A. Quraishi and A.K. Mukherjee, J. Mol. Liq., 2016, 215, 47. doi: $10.1016 /$ j.molliq.2015.12.027

31. M. Yadav, L. Gope, N. Kumari, P. Yadav, J. Mol. Liq., 2016, 216, 78. doi: $10.1016 /$ j.molliq.2015.12.106

32. D.K. Singh, S. Kumar, G. Udayabhanu and R.P. John, J. Mol. Liq., 2016, 216, 738. doi: $10.1016 /$ j.molliq.2016.02.012

33. M.N. El-Haddad and K.M. Elattar, Int. J. Ind. Chem., 2015, 6, 105. doi: 10.1007/ s40090-015-0037-9.

34. N.O. Obi-Egbedi and I.B. Obot, Arab. J. Chem., 2013, 6, 211. doi: 10.1016/j.arabjc. 2010.10.004

35. A. Bousskri, A. Anejjar, M. Messali, R. Salghi, O. Benali, Y. Karzazi, S. Jodeh, M. Zougagh, E.E. Ebenso and B. Hammouti, J. Mol. Liq., 2015, 211, 1000. doi: 10.1016/j.molliq.2015.08.038

36. B. El Makrini, H. Lgaz, K. Toumiat, R. Salghi, S. Jodeh, G. Hanbali, M. Belkhaouda and M. Zougagh, Res. J. Pharm. Biol. Chem. Sci., 2016, 7, 2277. 
37. B. El Makrini, K. Toumiat, H. Lgaz, R. Salghi, S. Jodeh, G. Hanbali, M. Belkhaouda and M. Zougagh, Res. J. Pharm. Biol. Chem. Sci., 2016, 7, 2286.

38. K. Toumiat, Y. El Aoufir, H. Lgaz, R. Salghi, S. Jodeh, M. Zougagh and H. Oudda, Res. J. Pharm. Biol. Chem. Sci. 2016, 7, 1210.

39. K. Toumiat, Y. El Aoufir, H. Lgaz, R. Salghi, S. Jodeh, M. Zougagh and H. Oudda, Res. J. Pharm. Biol. Chem. Sci., 2016, 7, 1209.

40. Y. El Aoufir, H. Lgaz, K. Toumiat, R. Salghi, S. Jodeh, M. Zougagh, A. Guenbour and H. Oudda, Res. J. Pharm. Biol. Chem. Sci., 2016, 7, 1200.

41. Y. El Aoufir, H. Lgaz, K. Toumiat, R. Salghi, S. Jodeh, M. Zougagh, A. Guenbour and H. Oudda, Res. J. Pharm. Biol. Chem. Sci., 2016, 7, 1219. 